\title{
Real Option Analysis versus DCF Valuation - An Application to a Tunisian Oilfield
}

\author{
Lotfi TALEB ${ }^{1}$ \\ ${ }^{1}$ ESSEC, Tunis, Tunisia \\ Correspondence: Lotfi TALEB, ESSEC, Tunis, Tunisia. \\ Received: January 2, 2019 \\ Accepted: January 18, 2019 \\ Online Published: January 29, 2019 \\ doi:10.5539/ibr.v12n3p17 \\ URL: https://doi.org/10.5539/ibr.v12n3p17
}

\begin{abstract}
The most widely used methods of choosing investments are undoubtedly the NPV. This method is often criticized because it does not allow to take into account certain main characteristics of the investment decision, notably the irreversibility, the uncertainty and the possibility of delaying the investment. On the other hand, the real options approach (ROA) is proposed to capture the flexibility associated with an investment project. This article examines whether the value of an undeveloped oil field varies according to whether the ROA or NPV assessment is used. In addition, to value the option to defer, we developed a continuous time model derived from previous work by Brenan and Schwartz (1985), McDonald and Siegel (1986) and Paddock, Siegel, and Smith (1988). The originality of the proposed model gives rise to a simple and uncomplicated method for determining the value of the option. Findings indicate that the two evaluation methods lead to the same decision, the project is economically profitable. In this oil investment project studied, despite the positive value of the option, the importance of projected cash-flows and optimistic forecasts of the price of oil, led us not to exercise the option and to undertake the project immediately.
\end{abstract}

Keywords: NPV, continuous model, real option analysis, sensitivity analysis, theoretical model, Tunisian oilfield JEL classification: G11, G00

\section{Introduction}

The theory of investment postulate that a firm should invest in a project as long as the present value of the expected stream of profits that this project will generate should exceed or be equal to the present value of expenditure stream required to build the project. This classic method of the net present value (NPV) or discounted cash flow (DCF), is not capable to take account of some main characteristics of the investment decision in particular, the irreversibility, the uncertainty and the possibility of deferring the investment decision and so, ignores flexibility with regard to the timing of the investment decision.

Several previous studies, [ Myers (1977), Schwartz, Dixit and Pindyck (1994), Ross (1995), Herder et al. (2010), Haque et al. (2014) )], have shown that, in terms of investment analysis in an uncertain environment, the use of traditional NPV or DCF to make decision, may produce a biased result of an investment program.

Modern finance theory gives us an interested support to value this flexibility and the possibility to defer the investment by using the ideas based on the pricing model of Black and Scholes (1973) and applying them to enhance real world projects. Thinking about how future circumstances affect the value of projects has therefore come to be known as the area of the real options approach (ROA).

A real option (RO) is an option generated by an investment project, the owner of the real option, as is the holder of a financial option, have the right and not the obligation to take a decision on a future date. This RO is generated by the characteristics of an investment project. When a firm makes an irreversible investment it can be assimilated to an exercise of an option to invest. Doing so, the firm can have the possibility to waiting for new information that can arrive and this may affect the decision to invest immediately (expand, defer or abandon). The loss of this option can be considered as an opportunity that must be included as a part of the cost of investment.

The logic in this ROA is to emphasize that going through with an irreversible investment means foregoing the opportunity to wait for new information, thereby taking on an opportunity cost, which should be included in the 
investment decision. McDonald and Siegel (1986) give proven that with even moderate levels of uncertainty, the value of this opportunity cost can be large, and an investment rule that ignores it will be grossly in error.

The ROA has been used in several areas, in particular, natural resources investment [Brennan and Schwartz (1985), Trigeorgis (1990)]; land development [Quigg (1993), Capozza and Sick (1994)]; R\&D [Morris, Teisberg and Kolbe (1991)]; firms' valuation [Kellogg and Charnes (2000), Schwartz and Moon (2000)]; energy sector [Elder and Serletis (2010), Fernandes et al. (2011), Fan and Zhu (2010), Fan et al. (2013)] ; mineral resources [Brenan and Schwartz (1985), Haque et al.(2014), Myers and Read (2012)].

Many theoretical models were also developed to test the pertinence of the ROA, Dixit and Pindyck (1995) developed a pricing model of a petroleum investment and show that it may significantly underestimate its value if it ignores the flexibility available to the owner about the timing of the development. Myers and Majd (1987) have incorporated the possibility of abandoning a project through a continuous time model. Brenan and Schwartz (1985) integrated the possibility of stopping production with the use of the temporary shutdown option. Luehrman (1998), based on an application in the pharmaceutical investment, propose a two dimensions model to valuation of real options. Penning and Lint (1997) demonstrated the relevance of using the ROA in $\mathrm{R} \& \mathrm{D}$ area.

In petroleum industry The ROA was first introduced by Paddock et al. (1988), their study extended financial option theory by developing a methodology for the valuation of an offshore petroleum oilfield by combining financial option pricing tools with a model of equilibrium in the market for petroleum reserves. As Paddock et al. (1988), several other studies have tried to proceed with the valorization of a petroleum lease through an ROA [Dickens and Lohrenz (1996), Cortazar and Schwartz (1998), Zettl (2002), Brandão et al. (2005)]

The present paper studied the pertinence of the use of the ROA in the investment decision. More precisely, the paper developed a theoretical model to compare the NPV method and the ROA to investment decision making and then, to explain in which circumstances NPV analysis and ROA differ as basis for decision making about a Tunisian oil field investment. Compared to other models and previous calculation methods, the developed model in this paper gives rise to a simple and uncomplicated method for determining the value of the option to defer.

The remainder of the paper is organized as follows. In section 2 we develop the methodology of ROA and the DCF in energy investment evaluation. Section 3 contains an overview of Tunisian Petroleum legislation and data collected. Section 4 discusses the results of the two methods when applied to the evaluation of the petroleum investment project. Section 5 concludes.

\section{Methodology}

\subsection{The NPV Evaluation}

The DCF method of calculating project net present value is the most widely accepted valuation method. The basic premise of the conventional NPV method is to estimate future cash flows from an investment outlay (revenues and costs) and discount them to a common present time using a hurdle rate (discount rate) or a risk-adjusted rate of return (WACC). The convention is to determine the net difference between estimated discounted revenue and discounted cost such that if the net is greater than zero, the investment is considered economically attractive. The aim of this deterministic method is to find expected present value of future income and costs, and to compare this value with projects' investment costs. The decision rule recommended by NPV method, states that if the current risk adjusted value of expected cash inflows exceed the value of cash outflows, then a project should be immediately undertaken.

The simple formula of NPV can be written as follows:

$$
N P V=-k_{0}+\sum_{t=1}^{n} \frac{C F}{(1+r)^{t}}
$$

With:

$k_{0}$ : Net present value of initial investment

$C F$ : The cash flows released by the project

$r$ : A discount rate 
With petroleum investment, and given the specificities of the project, the NPV can be expressed by the following formula:

$$
N P V=-k+\sum_{t=T}^{N} e^{-W A C C}\left[\left(Q_{t} S_{t}-C_{t} X_{t}\left(1-h_{t}\right)+h_{t} D_{t}\right]\right.
$$

Where,

$k$ : The net present value of initial investment

$N$ : The life of the oilfield once production has begun

WACC: The risk-adjusted continuous discount rate ${ }^{1}$

$Q_{t}$ : The number of barrels of oil to be extracted in year $\mathrm{t}$

$S_{t}$ : The estimated Brent spot price

$C_{t}$ : The total cost of production year $\mathrm{t}$

$X_{i}$ : The forward exchange rate year $\mathrm{t}$

$\mathrm{h}_{\mathrm{t}}$ : The corporate tax rate

$D_{t}$ : The planned depreciation year $\mathrm{t}$

This standard NPV approach implicitly assumes that managers will remain passive if the circumstances or the conditions change. Thus, even if market conditions change, the NPV rule assumes that managers will not alter their level of production or initial decision in response. In other words, the conventional NPV method supposes that the investment decision as a static, one off affair and that there is no scope for managers to react to new information. Furthermore, the NPV method assumes that initial decision is made just now, all cash flow streams are supposed to be fixed in the future and are highly predictable, and all categories of risks are accounted for by the discount rate.

The energy sector is a good example of an industry exposed to high investments and high uncertainty. The level of activity and the investment profitability is affected by many factors representing uncertainty and risk (oil price, technology, costs and inflation, Amount and the quality of the crude oil extracted, the issue of time etc...).

When applied in petroleum investment, the deterministic NPV method has major weaknesses that inhibit correct lease value determination [Schwartz, Dixit and Pindyck (1994)] $]^{2}$. In particular, (1) the choice of timing for the NPV calculations is chosen in most time arbitrary and then, is subject to error. (2) Petroleum companies, as well as the government, may have different assessments of future statistical distributions, and thus expected paths of hydrocarbon prices, none of which need to conform to the aggregate expectations held by capital markets. This also leads mostly to divergent valuations. (3) The manner to choose the correct set of risk-adjusted discount rates in the presence of the complex statistical structure of the cash flows is a complex task, and it can be subject to a great deal of subjectivity and error.

All these weaknesses can be partially solved by the ROA. The option valuation methodology is supposed to be not subject to these problems, for the simple reason it is purely a financial valuation tool. Moreover, some investment areas, such as the energy sector, can be valued with more flexibility and details by the ROA. Indeed, petroleum investment is often characterized by long-lived irreversible and uncertainty investments and it proved that the use of the ROA can reduce information requirements by eliminating the need to estimate future developed reserve values ${ }^{3}$ and also eliminating the need to determine the risk-adjusted discount rates ${ }^{4}$.

\footnotetext{
${ }^{1}$ The WACC can be calculated as a weighted average cost of capital, meaning the average rate of return demanded by investors in the company's debt and equity securities. The Capital Asset Pricing Model (CAPM) is very often used to calculate the company cost of equity.

${ }^{2}$ Schwartz, Dixit \& Pindyck (1994) achieve this result with the numerical analysis of a reasonable set of parameters that compares traditional DCF with the ROA.

${ }^{3}$ It should be noted that even using the market value of developed reserves, the DCF analyst would still need to make assumptions about the expected rate of appreciation of the value of a developed reserve.

${ }^{4}$ This is an important consideration, because the optimal investment-timing decision must take into consideration of the feedbacks between the investment-timing rule and the risk of the resulting cash flows. This problem is not present with the ROA.
} 


\subsection{The Real Option Approach (ROA)}

\subsubsection{Financial Option and Real Option: A Comparison}

A real option is generated by the characteristics of an investment project. In the case of an oil reserve and according to ROA, the investment decision can be taken in a sequential manner, each phase gives the right to carry out the next. As proposed by Brenan and Schwartz (1985), investment can be subdivided in three sequential steps, exploration ${ }^{5}$, development and extraction. The most important phase is probably the development phase. This phase need colossal investment amounts to convert an undeveloped reserve in a developed reserve. Then, to develop this reserve can be considered as a call option to obtain the underlying asset, the developed oil reserve, after payment of the exercise price, the cost of development.

Table 1 summarize a comparison between real and financial options and reports the similarities between the parameters in the Black and Scholes formula and a typical real option model.

Table 1. Analogy between financial and real option

\begin{tabular}{ll}
\hline Black \& Scholes Financial options & Real options (undeveloped reserve) \\
\hline Financial option value & Value of the undeveloped reserve \\
Current stock price & Present value of developed reserve \\
Exercise price of the option & Investment cost to develop the reserve \\
Stock dividend yield & Net convenience yield \\
Risk-Free interest rate & Risk-Free interest rate \\
Stock volatility & Volatility of developed reserve \\
Date of expiration of the option & Date of expiration of investment right \\
Variance of rate of return on the stock & Variance of rate of change of the value of the developed \\
& reserve \\
\hline 2.1 .2 Valuing the Option to Defer (Undeveloped Reserve)
\end{tabular}

2.1.2 Valuing the Option to Defer (Undeveloped Reserve)

Following the methodology of Brennan and Schwartz (1985), McDonald and Siegel (1986) and also, Paddock et al. (1988), the rate of return, Rt, is supposed to follow a Geometric Brownian Motion (GBM), as is given by the following equation:

$$
\begin{gathered}
R_{t} d_{t}=\mu_{v} B_{t} V_{t} d_{t}+\sigma_{v} B_{t} V_{t} d z_{v} \\
\frac{R_{t} d_{t}}{B_{t} V_{t}}=\mu_{v} d_{t}+\sigma_{v} d z_{v}
\end{gathered}
$$

With,

Bt: The number of units of petroleum in a developed reserve

Vt: The unit value (per barrel) of developed reserve

Rt: The instantaneous per unit time net payoff from holding the reserve at the time $t$.

$\mu \mathrm{V}$ : The market risk-adjusted (expected) return rate

$\sigma_{v}$ : The instantaneous per unit time standard deviation of the rate of return

The net payoff in petroleum investment comes mainly from two sources: (1) the profits from production; and (2) the capital gain on hold the remaining petroleum. Suppose that production from a developed reserve follows an exponential decline:

So, the net payoff can be written as follows:

$$
d B_{t}=-\lambda B_{t} d_{t}
$$

$$
R_{t} d_{t}=\left\{\lambda B_{t} \pi_{t} d_{t}\right\}+\left\{\left(1-\lambda d_{t}\right) B_{t}\left(V_{t}+d V_{t}\right)-B_{t} V_{t}\right\}
$$

With $\pi_{t}$ is the after-tax operating profit from selling a unit of petroleum

Substituting (3) and (2) in (1) we obtain the stochastic process generating the value of a producing developed reserve:

\footnotetext{
${ }^{5}$ Exploration phase consist of main activities include essentially, seismic 2D, seismic 3D, hydrocarbon resources estimate and drill exploratory well.
} 


$$
\begin{gathered}
\frac{\mathrm{dV}}{\mathrm{V}}=\left(\mu_{\mathrm{V}}-\delta_{\mathrm{t}}\right) \mathrm{d}_{\mathrm{t}}+\sigma_{\mathrm{V}} \mathrm{dZ} \mathrm{Z}_{\mathrm{V}} \\
=\alpha_{\mathrm{t}} \mathrm{d}_{\mathrm{t}}+\sigma_{\mathrm{V}} \mathrm{dZ} Z_{\mathrm{V}}
\end{gathered}
$$

With,

$$
\alpha_{\mathrm{V}}=\mu_{\mathrm{V}}-\delta_{\mathrm{t}}
$$

$$
\text { And, } \quad \delta_{t}=\frac{\lambda\left[\pi_{t}-V_{t}\right]}{V_{t}}
$$

$\delta_{t}$ : is the payout rate of the producing developed reserve, and $\alpha_{V}$ is the expected rate of capital gain. ${ }^{6}$

In order to evaluate the value of the option to defer $(\mathrm{F})$, we consider the following parameters

$\mathrm{F}(\mathrm{V}, \mathrm{T}-\mathrm{t}, \mathrm{D}(\mathrm{q}))$ : The value of the option to defer i.e. the value of undeveloped reserve

$\mathrm{V}$ : The unit value (per barrel) of developed reserve

Q: The amount of oil existing in developed reserve

D (Q): The unit cost of development witch supposed a function of the quantity $\mathrm{Q}$

t: The current time

T: The expiration date

Based on arbitrage argument, the value of the developed reserve can be written as:

$$
\frac{\partial F}{\partial t}=\frac{1}{2} \sigma_{V}^{2} V^{2} \frac{\partial^{2} F}{\partial V^{2}}+(r-\delta)-r F
$$

With $r$ is the risk free rate, assumed to be constant over the entire life of the project.

Following Merton [1973], McDonald and Siegel [1986] and also, Paddock, Siegel, and Smith (1988), resolving this differential equation must satisfy the following boundary conditions:

$$
\begin{aligned}
& F(0 ; t)=0 \\
& F(V ; t)=\operatorname{Max}\left[V_{t}-D ; 0\right] \\
& F\left(V^{*} ; t\right)=V^{*}-D \\
& F^{\prime}\left(V^{*} ; t\right)=1
\end{aligned}
$$

With $D$ is the value of development cost (per barrel) of the developed reserve, and $V^{*}$ is the critical value of investment i.e. the value beyond which the investment decision by the ROA is recommended.

To solve the differential equation analytically, under the assumption that of a developed reserve is assimilated to a perpetual option, we will be able to determine the solution of the differential equation, given as follows ${ }^{7}$ :

$$
\mathrm{F}\left(\mathrm{V}^{*}\right)=\mathrm{AV}^{* \beta_{1}}
$$

With

$$
V^{*}=\frac{\beta_{1}}{\beta_{1}-1} D
$$

\footnotetext{
${ }^{6}$ It be supposed that, $\alpha_{V}, \delta_{\mathrm{t}}$ and $\sigma_{V}$ are constant over the life of the lease and then, the value of developed reserve $(V)$ following a MBG.

${ }^{7}$ For more details and demonstration refers to McDonald and Siegel [1986] and Paddock, Siegel, and Smith' (1988) studies.
} 


$$
\begin{aligned}
& A=\frac{V^{*}-D}{\left(V^{*}\right)^{\beta_{1}}} \\
& \beta_{1}=\frac{1}{2}-\frac{(r-s)}{\sigma^{2}}+\sqrt{\left[\frac{r-\delta}{\sigma^{2}}-\frac{1}{2}\right]^{2}+\frac{2 r}{\sigma^{2}}}
\end{aligned}
$$

Accordingly, to the ROA, the decision rule state that we should only invest if, $V>V *$ and not if $V>I$. So, as soon as the current value of the developed reserve exceeds a given critical value of investments, the investment decision becomes possible, and investment should be to this date undertaken.

\section{Data $^{8}$}

\subsection{Tunisian Tax and Fees Oil System}

Table 2 summarize an overview of petroleum fiscal and legislation landscape in Tunisia ${ }^{9}$

Table 2. Overview of petroleum fiscal and legislation landscape in Tunisia

\section{Legal framework \\ Type of licenses}

\section{Contractual regime}

Income Tax rate

Royalty tax

Incentives

Contractor domestic obligation

The State owns hydrocarbon deposits.

The Hydrocarbon Code provides for four types of licenses:(1) A prospecting authorization enables the holder to perform preliminary prospecting works with the exception of any seismic works and drilling wells (1 year) (2) A prospecting permit enables the holder to perform prospecting work (exclusive right) within a defined area (2 years) (3) An exploration permit enables the holder to perform the works set out in the exploration work program and (5 years) (4) An exploitation concession is granted when a commercial discovery is made during the period of the exploration permit ( 30 years with possible renewals).

There's mainly two contractual regimes, (1) a joint venture agreement contract (JVAC) signed by the ETAP' company and the Private Oil Company, (2) a production sharing contract $(P C C)$ entered into between ETAP and the contractor. Within the first type contract, the ETAP benefits from an option to take a participating interest in the exploitation concession and The contractor usually bears the expenses and risks of prospecting and exploration activities (but ETAP may choose to participate in the exploration expenses with the consent of the State while in the second form of contract the ETAP' company is entitled to a share of the hydrocarbon production and must reimburse a percentage of the prospecting and exploration costs as agreed under the production sharing contract.

The Income tax rate in Tunisia varied between $50 \%$ and $75 \%$ depending to " $R$ " factor which is a ratio between (1) the Accumulated net revenues and (2) Accumulated expenditures.

An additional tax, as a royalty on production, must be paid and it's depending also on $K$ factor $(<15 \%)$.

As a Tax incentives, the company have the right to build up an investment reserve in the limit of $20 \%$ of the taxable income intended to finance Prospecting and Exploration activities.

The foreign company has a Domestic Market Obligation (DMO) which state that a percentage of $20 \%$ of production must be sold in the domestic market at a discount to International prices.

3.2 Collected Data ${ }^{10}$

We consider, to evaluate the petroleum investment, the following parameters collected mainly from the ETAP Company

1) The exploration permit named "ARAIFA" is accorded by Tunisian state in 2011 and terminate at 2018.

2) The investment must begin, if the profitability of the reserve is proved, on 2019, the contact that will be signed is a production sharing contract $(P C C)$.

3) The size of the reserve or the amount of hydrocarbon is estimated at 17.528 million existing barrels (that can be increased to 40 million of barrels).

\section{${ }^{8}$ Source: ETAP company}

${ }^{9}$ All data as well as the Tunisian petroleum legislation are obtained from ETAP company 'experts, and also public information's available from the website www.etap.com.tn

${ }^{10}$ Source : ETAP company 
4) The expected amount of oil that will be produced per day is at least of 15 thousand barrels. The quantity of production will peak in the second year of operation. At that time this amount is estimated at 1.940 million barrels (insert figure 1)

5) Exploration costs amounted to 20 US $\$$ Million.

6) The development cost (the value of the investment) is equal to 50.995 U.S. dollars Million. The investment will be made sequentially over 5 years (2018-2022) ( insert figure 2)

7) The production, if the project is described as profitable, start at the end of 2019.

8) The initial investment will be amortized from the year 2019 at, $20 \%$ the first year, $30 \%$ second and third years, and $20 \%$ the fourth year.

9) All the natural gas present in the oilfield will not be considered in the valuation, since it constitutes a minor part of project value.

10) The average decline rate is estimated to be equal to $6 \%$ (approximately).

11) The operation life of the oil reserve is estimated at least 20 years.

12) The present investment will be funded by a credit banking loan in U.S. dollars (65\%), the rest (35\%) by owned funds.

13) The beta factor in energy and Gas sector (mean) is supposed to be equal to 1 (insert figure 3 )

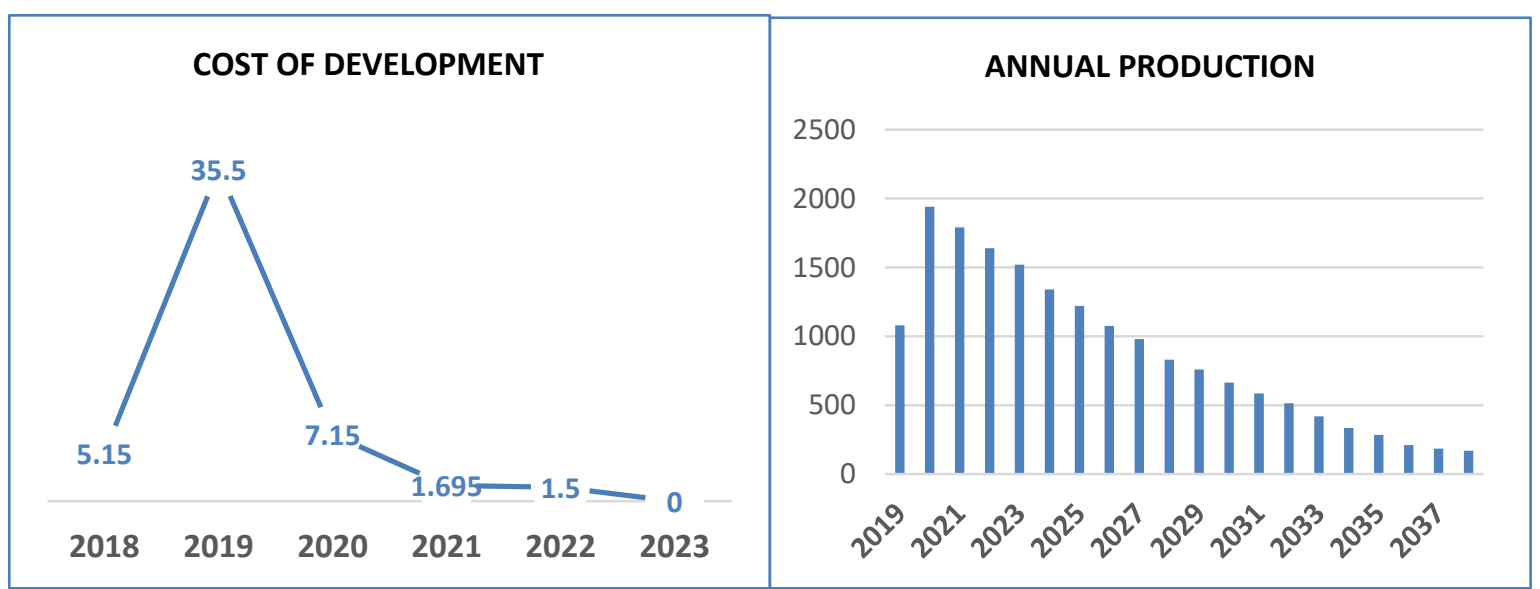

Figure 2. Forecasted project cost of development (ETAP) Figure 1. Forecasted project annual production (ETAP)

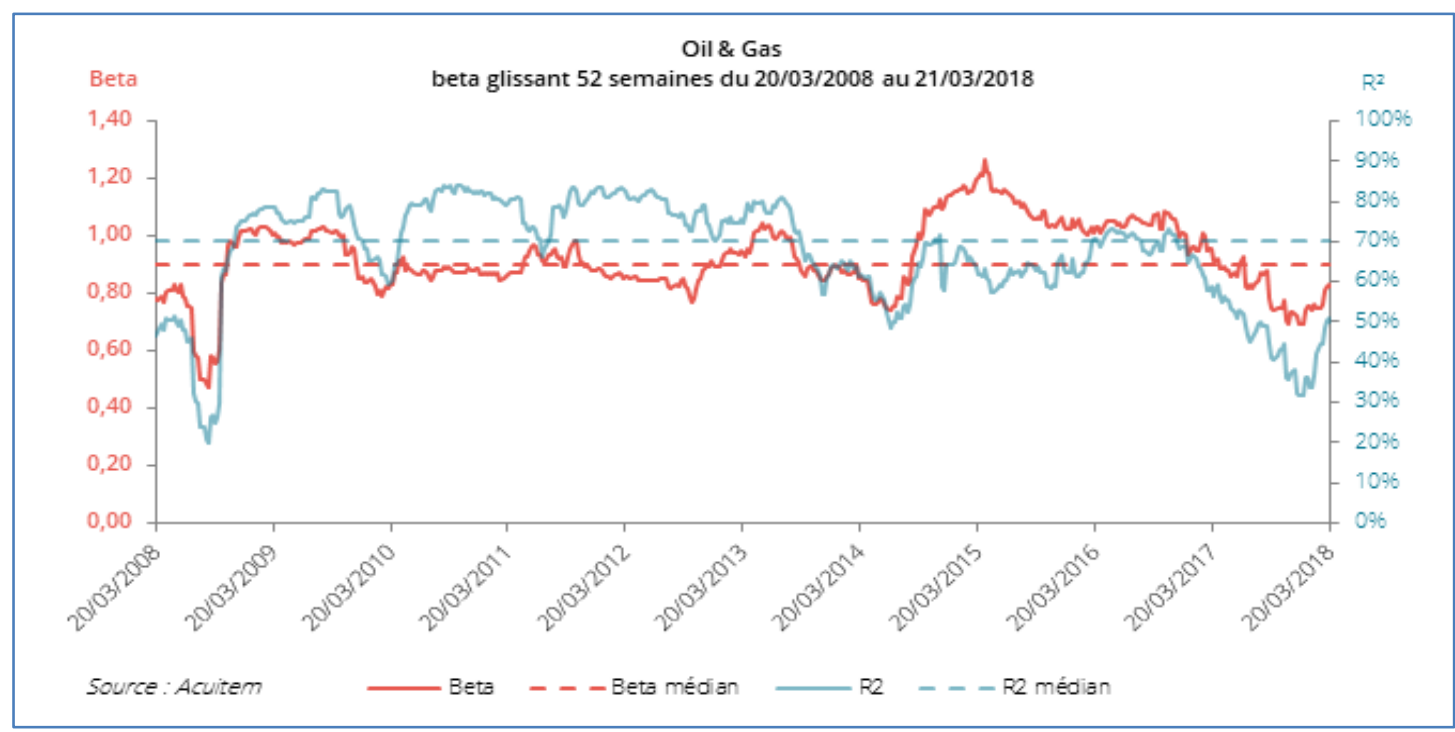

Figure 3. Oil and Gas beta factor (source: www.acuitem.com)

Table 3 reports oilfield characteristics and all financial parameters used in the DCF valuation. 
Table 3. Oilfield characteristics and financial parameters ${ }^{11}$

\begin{tabular}{lc}
\hline Parameters & Data \\
\hline Volume of estimated oil & $17,528 \mathrm{Mstb}$ \\
Relinquishment requirement** & 5 years \\
$R$ factor & $1<R<1.5$ \\
Royalty factor & $10 \%$ \\
Assumed debt ratio & $65 \%$ \\
Estimated levered Beta*** & 1 \\
Corporate tax rate & $50 \%$ \\
Assumed risk premium & $13 \%$ \\
US. ten-year government bond 2018-12-02**** & $3 \%$ \\
Cost of debt & $14 \%$ \\
Resulting WACC****** & $10 \%$ \\
\hline
\end{tabular}
(*) Millions of stock tank barrels
(**) Used only in the real option valuation
$(* * *) \quad$ See figure 3
(****) Given the value of the $R$ factor
(*****) Source: www.treasury.gov
$(* * * * * *) \quad$ The WACC has been determined using estimates of the debt ratio,
beta and an assumed risk premium to calculate the cost of equity

\section{Real Option Analysis versus DCF Valuation}

\subsection{DCF Valuation}

Considering all these data presented before, oilfield characteristics and financial parameters and calculated forecasted cash flows (insert figure 4), by the application of the formula (8) the NPV method gives a positive value (11851.350). The recommended decision rule supposes, then that the investment is profitable. The decision rule given by this method recommended that the project is economically justified and should be then immediately taken.

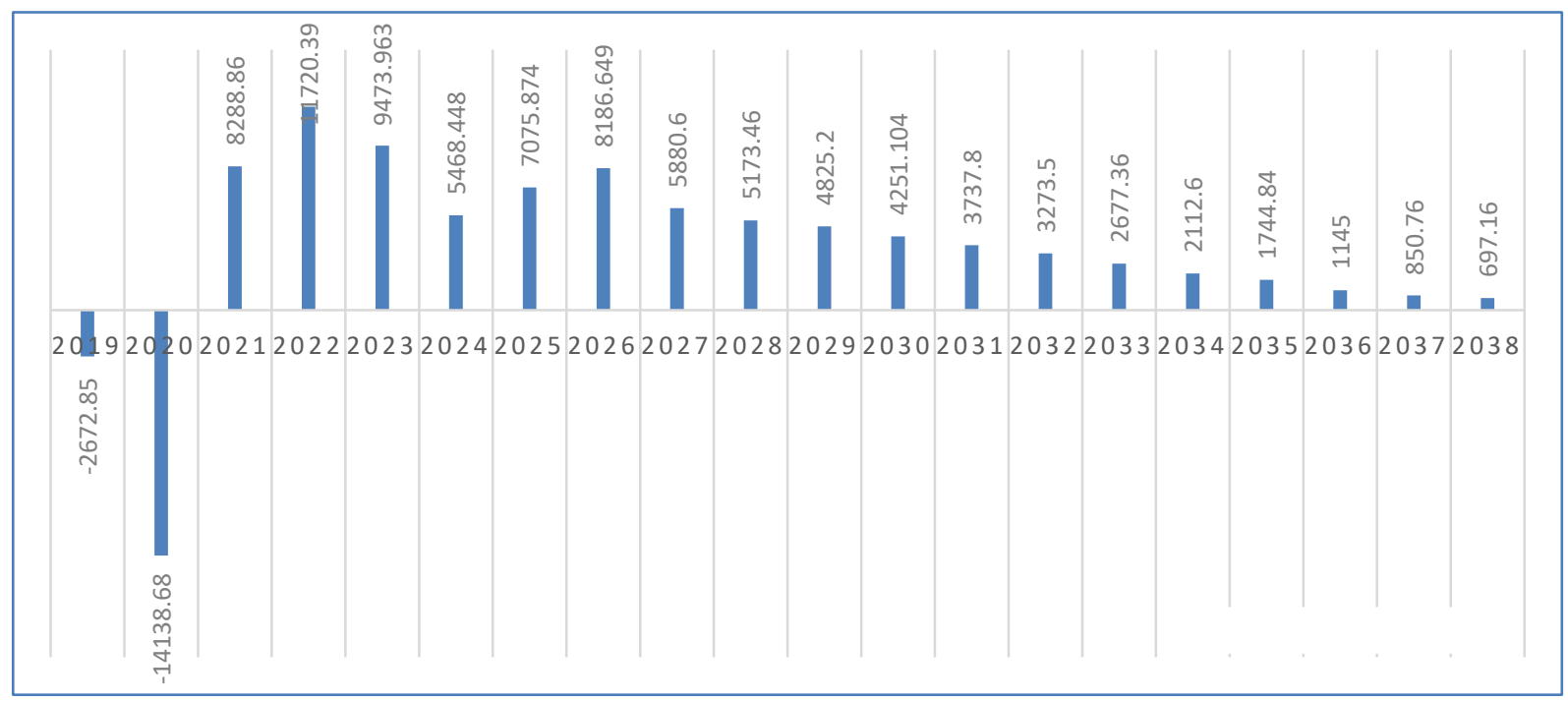

Figure 4. Forecasted all project Cash Flows

This result found by this deterministic method must be interpreted with caution due to many errors that can be committed in using the NPV method. In particular, (1) the choice of the date of exploration and development is an arbitrary choice, therefore, subject to more errors, (2) The oil company and the government can have different estimates about the distribution of cash flows, and also (3) the oil price and the process of choosing the discount

\footnotetext{
${ }^{11}$ Source: ETAP company and author's calculations
} 
rate can involve highly complex statistical tools and will be mostly guided by subjective data. All these errors can be partially corrected by using the ROA.

Moreover, there are two apparent advantages of the ROA over DCF. First, the ROA approach reduces information requirements by eliminating the need to estimate future developed reserve values. Even using the market value of developed reserves, the DCF analyst would still need to make assumptions about the expected rate of appreciation of the value of a developed reserve. Second, the ROA approach eliminates the need to determine risk-adjusted discount rates, because the optimal investment-timing decision must take account of the feedbacks between the investment-timing rule and the risk of the resulting cash flows.

\subsection{Real Option Analysis}

\subsubsection{The Parameters of the Option to Defer}

In order to value of the option to defer i.e. the value of the undeveloped reserve, we must determine at first all the financial parameters needed, in particular the volatility of developed reserve, the net convenience yield, the present value of the developed reserve and the investment cost to develop the petroleum reserve into developed reserve.

\subsubsection{Volatility of Developed Reserve (Stock Volatility): $\sigma_{q}^{2}$}

To calculate the volatility of reserves developed, we must have the historical data of developed reserves, but these data are not available on the Tunisian context ${ }^{12}$, and the value of the volatility affects the value of the option. To determine the volatility of developed reserve supposed to obtain past data on market values of developed reserves or the value of volatility for a similar existent reserve that has the same hydrocarbon quality, cost structure, and tax regime. Unfortunately, this information is not available in Tunisian context, we choose then to approximate the volatility of reserves developed, as Paddock et al. (1998), by the volatility of fuel prices. We suppose, that the rate of change in crude prices follows a lognormal distribution. Given this assumption, the variance of the rate of change in crude prices is equal to the variance of the developed reserve. This variance can be developed as follows:

$$
\sigma_{q}^{2}=\sum_{t=T-N}^{k-1} \frac{\left(R_{t}-\bar{R}\right)^{2}}{N}
$$

With, $R_{t}=\log \left(\frac{P_{t+1}}{P_{t}}\right), P_{t}$ is Crude oil prices observed on period $t$ and, $N$ is the sample size (number of observations).

Based on a sample of monthly quotations of crude oil during the period 2010-2018 (insert Figure 5), we calculate an annual variance $\left(\sigma_{q}^{2}=13.55\right)$.

\footnotetext{
${ }^{12}$ In general and, according to Lima and Suslick (2006), in oil project valuation and investment decision-making, volatility is a key parameter, but it is difficult to estimate this parameter, moreover the estimation of project volatility is very complicated since there is not a historical series of project values. With DCF method, volatility reduces the project value because it increases its discount rate via a higher risk premium. Contrarily, according to the ROA, volatility may aggregate value of the project, since the downside potential is limited whereas the upside is theoretically unbounded.
} 


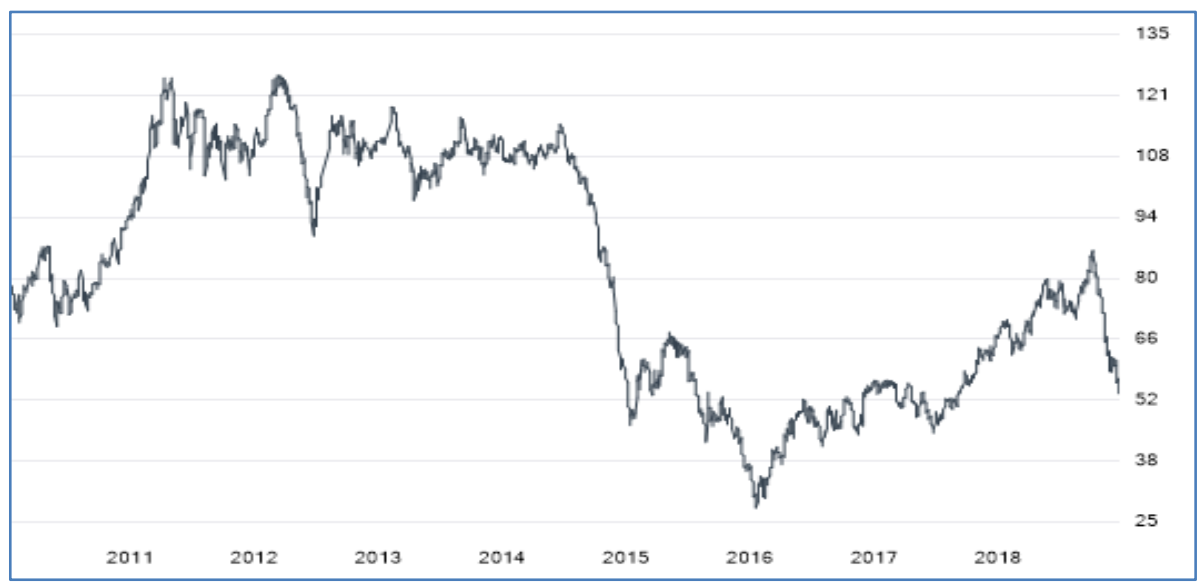

Figure 5. Crude oil prices between year 2010-2018 (Source: www. boursier.com)

\subsubsection{Net Convenience Yield (Stock Dividend Yield): $\delta_{t}$}

To evaluate to option to defer attached to the petroleum investment, we must determine in the net convenience yield for producing reserve, as given on equation (7) developed above.

Given, the Gruy et al. (1982) "one-third" assumption mentioned above, the after-tax barrel profit from production $\left(\pi_{t}\right)$ can be calculate as follow:

$$
\pi_{t}=M_{t}-O C_{t}-\tau\left(M_{t}-O C_{t}-D A_{t}\right)
$$

With,

$M_{t}$ : Market price (per barrel) of crude oil,

$O C_{t}$ : Operating cost, per barrel (including royalty)

$D A_{t}$ : Depreciation allowance, per barrel

The convenience yield, as an alternative cost, suggests that the value of the possibility of waiting and the delaying the investment, decreases as the benefit of holding crude oil increases. On the contrary, when the convenience yield decreases or becomes negative, the value of the option to defer investment increases. The calculation of the convenience yield value is given in the following table (insert Table 4).

Table 4. Determination of the convenience yield value

\begin{tabular}{ccccc}
\hline years & $\boldsymbol{V}_{\boldsymbol{t}}$ & $\boldsymbol{\pi}_{\boldsymbol{t}}$ & $\boldsymbol{\lambda}$ & $\boldsymbol{\delta}_{\boldsymbol{t}}$ \\
\hline 2019 & 16200 & 6,53 & 0,0616 & 0,018941 \\
2020 & 30264 & 10,81 & 0,1106 & 0,11944 \\
2021 & 28998 & 12,37 & 0,1021 & 0,131828 \\
2022 & 27552 & 11,41 & 0,0935 & 0,107919 \\
2023 & 26600 & 7,84 & 0,0857 & 0,02997 \\
2024 & 23852 & 7,39 & 0,0761 & 0,018845 \\
2025 & 22204 & 10,84 & 0,0696 & 0,054842 \\
2026 & 20102 & 7,29 & 0,0613 & 0,0103 \\
2027 & 18240 & 7,25 & 0,0547 & 0,008 \\
2028 & 16434 & 7,42 & 0,0473 & 0,0058 \\
2029 & 15580 & 7,57 & 0,0433 & 0,0047 \\
2030 & 14161 & 7,6 & 0,0381 & 0,0028 \\
2031 & 12870 & 7,7 & 0,0331 & 0,0051 \\
2032 & 11587 & 7,7 & 0,0239 & 0,0027 \\
2033 & 9744 & 7,76 & 0,0238 & 0,0008 \\
2034 & 8040 & 7,74 & 0,0191 & 0 \\
2035 & 7011 & 7,59 & 0,0162 & 0 \\
2036 & 5250 & 6,95 & 0,0119 & 0 \\
2037 & 4717 & 6,12 & 0,0105 & 0 \\
2038 & 4539 & 5,7 & 0,0096 & 0 \\
\hline
\end{tabular}




\subsubsection{Present Value of Developed Reserve (Underlying Asset)}

As Paddock et al. (1988), we applied the hypothesis of Gruy et al. (1982). This assumption, named "one third", state that the value of developed reserve prices tends to be about one third of crude oil price, $\left(V_{t}=P_{t} / 3\right)$, with $\mathrm{P}_{t}$ is the annual average price of crude oil. Given this assumption, we can use the variance of the rate of change of crude oil prices as a proxy for the variance of the rate of change of developed reserve prices.

Using monthly data for the period 2000-2018, the annualized variance of crude oil is about (13.55) (insert figure 5).

The present value of the developed reserve (underlying asset) can be given by the following formula:

$$
V_{t_{0}}=\sum_{t=1}^{20} V_{t} e^{-\delta t}
$$

\subsubsection{Investment cost (Exercise price of the option)}

The exercise price is the net present value of the cost of the development which can be calculate as follow:

$$
D_{t_{0}}=\sum_{t=1}^{20} I_{t} e^{-\delta t}
$$

Table (5) resume all the parameters needed to evaluate the value of the option, the undeveloped reserve.

Table 5. Financial parameters needed to evaluate the option to defer

\begin{tabular}{ccccc}
\hline parameters & $\sigma_{q}^{2}$ & $\delta$ & $V$ & D \\
\hline & $\mathbf{1 3 . 5 5}$ & $\mathbf{3 . 9 5 \%}$ & $\mathbf{2 4 2 1 6 8}$ & $\mathbf{4 8 4 6 8 . 8 7}$ \\
\hline
\end{tabular}

4.2.2 Valuing of the Option to Defer

All parameters are now available, we are now able to calculate the value of the option to defer attached to the oil reserve. This value can be given by the formula (10) given above.

Table (6) summarize the real option value

Table 6 . The value of the option to defer according to the ROA

\begin{tabular}{cccc}
\hline $\boldsymbol{\beta}_{\mathbf{1}}$ & $\boldsymbol{V}^{*}$ & $\mathbf{A}$ & $\boldsymbol{F}\left(\boldsymbol{V}^{*}\right)$ \\
\hline 1.3523 & 186046,826 & 0,01029 & $\mathbf{1 3 7 5 7 7 . 9 5 6}$ \\
\hline
\end{tabular}

4.2.3 ROA Decision Rule

Given these results, the project's NPV is positive (NPV $=11851.530$ ), the oil company can take profit in realizing this oil project as long as the critical value $\left(V^{*}=137577.956\right)$ is less than the current value of the developed reserve $(V=242168)$, and therefore, under the decision rule recommended by the real options method, the investment must be made immediately and it should not be delayed. In the case of this petroleum investment, we can then easily observe that the two methods lead to the same conclusion. But despite that the conclusion is the same, there is a large difference between the two approaches.

In the case of the new investment rule based on the ROA, we must not invest when $V>I$, but when $V>V^{*}$, with $V^{*}>I$. The difference between the critical value of investment $\left(V^{*}\right)$ and the value of investment $(I)$ is the option value of waiting owned by the oil company. This option gives the possibility to defer the investment decision. The error will be committed is therefore, to believe that the development cost of reserves at initial date is equal only to the cost of development, but this cost is more important, it is equal to the cost of development plus the value of the option to defer i.e. the full cost of the investment.

In the case of the investment project we dealt with, although the value of waiting option is high (three times greater than the cost of development), the importance of cash flows generated by the investment leads to realize this investment as soon as possible, even if the act of investment will generate to lose the value of the option to defer (insert figure 6). 


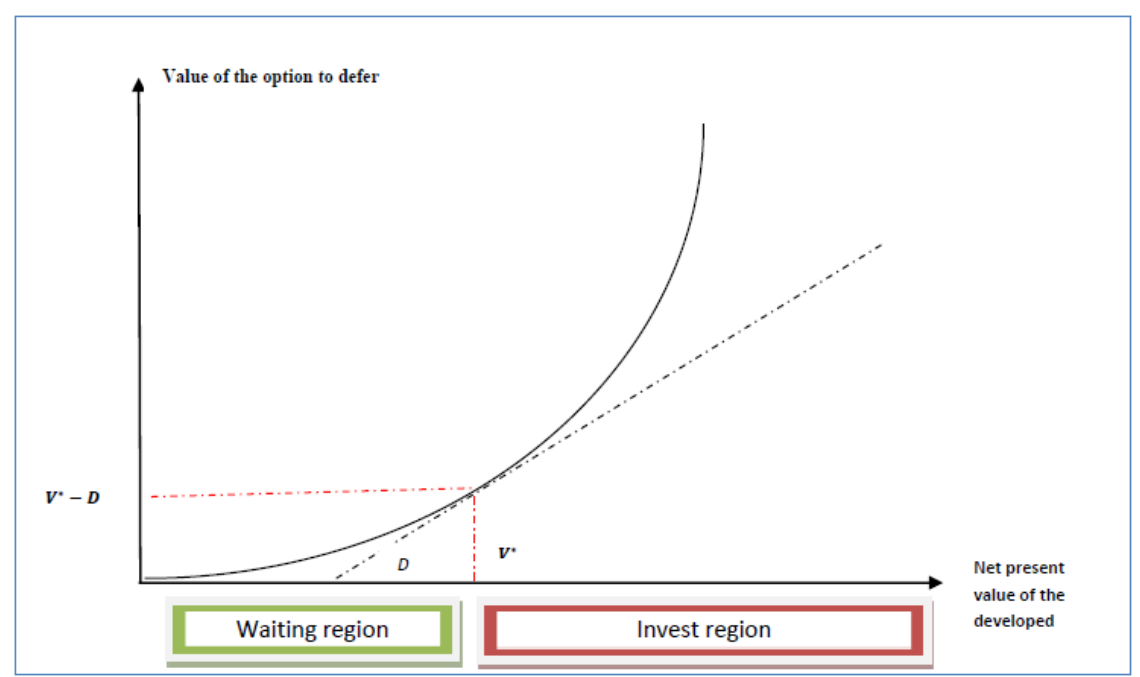

\subsubsection{Sensitivity Analysis}

Figure 6. Decision rule according to the ROA

As long as we don't have exactly the true value of the volatility and we are obliged to approximate the value by the volatility observed in crude oil, and as the value of RO increases with volatility and risk, we choose in this paragraph to calculate the sensitivity of the value of the option to defer, the critical value of the investment, and also the decision rule given by the ROA, regarding the change in risk i.e. the variation of the volatility of the developed reserve (insert Table 7).

Table 7. The sensitivity of the option to defer regarding the volatility of the developed reserve

\begin{tabular}{cccccccc}
\hline $\boldsymbol{\sigma}^{\mathbf{2}}$ & $\mathbf{2 \%}$ & $\mathbf{5 \%}$ & $\mathbf{1 0 \%}$ & $\mathbf{2 0 \%}$ & $\mathbf{2 2 \%}$ & $\mathbf{2 5 \%}$ & $\mathbf{5 0 \%}$ \\
\hline $\boldsymbol{V}^{*}$ & 67626.52 & 123988.44 & 161326 & 229660 & 242168 & 261847 & 420680 \\
$\boldsymbol{F}\left(\boldsymbol{V}^{*}\right)$ & 19157.65 & 75519.57 & 112857.13 & 181191.13 & 193699.13 & 213378.25 & 371899.13 \\
Decision & $V^{*}<V$ & $V^{*}<V$ & $V^{*}<V$ & $V^{*}<V$ & $V^{*}=V$ & $V^{*}>V$ & $V^{*}>V$ \\
rule & (Invest) & (Invest) & (Invest) & (Invest) & (Indifferent) & (Wait) & (Wait) \\
\hline
\end{tabular}

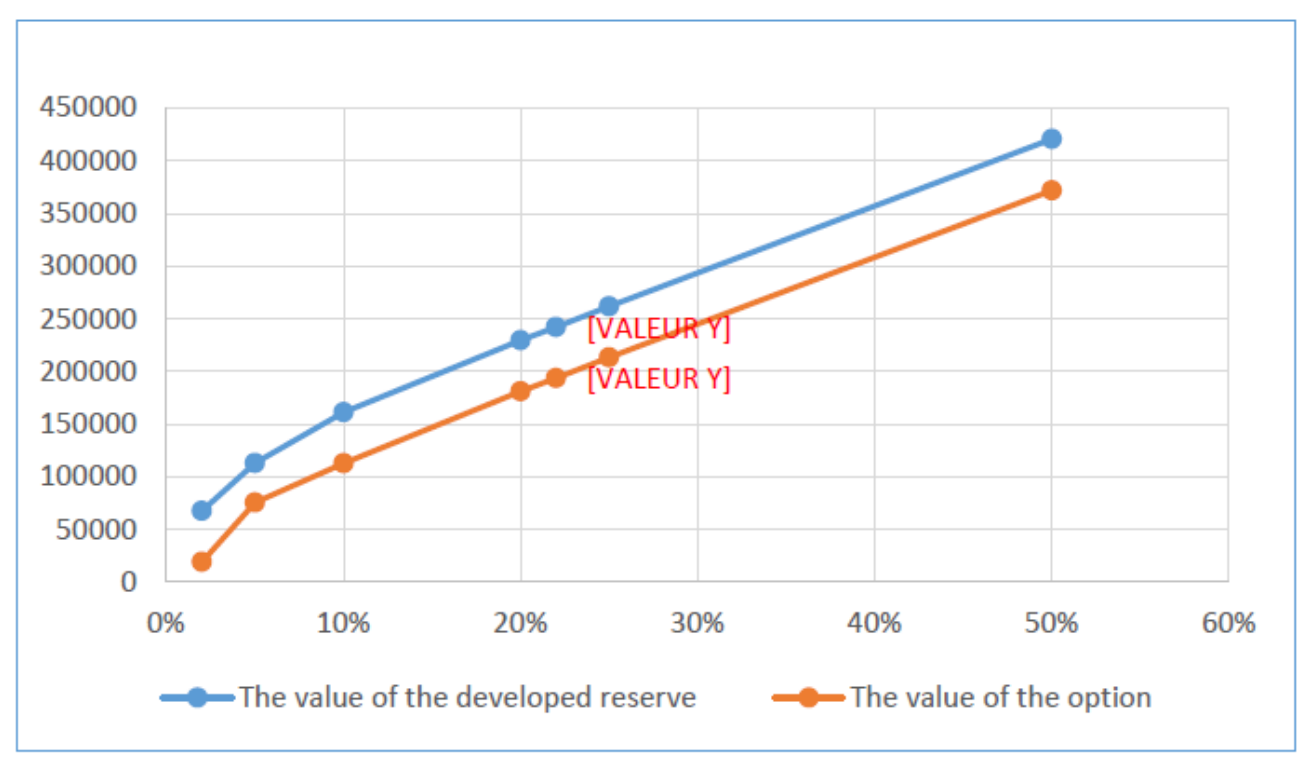

Figure 7. Sensitivity analysis of the option to defer to the variance of the underlying asset (developed reserve)

\section{Concluded}

The inability of the NPV approach to correctly value the different options embedded in investment strategies can lead to poor or even wrong investment decision making, particularly where the environment is characterized by, 
irreversibility, uncertainty and managerial flexibility.

The present paper extended financial option theory by developing the ROA to valuing a claim on a real asset: a Tunisian offshore petroleum lease. To value the option to defer, we developed a continuous time model derived from the former studies of Brenan and Schwartz (1985), McDonald and Siegel (1986) and Paddock et al. (1988). Compared to others theoretical models and calculation methods developed in the financial literature, the developed model in this paper, gives rise to a simple and uncomplicated method for determining the value of the option.

The results obtained show that the two methods (NPV and ROA), lead to the same decision: the project is economically profitable and it should be immediately undertaken. But, although the option to defer is very important, the importance of cash flows generated by the investment lead to realize it immediately and then, not to choose the exercise the option to defer.

Finally, and as underlying by Dixit and Pyndick (1995), there are many other real assets with option-like characteristics. The kinds of informational economies, insights, and problems discussed in this paper in relation to valuing petroleum leases may be present in valuing claims on other real assets as well. An interesting extension to this framework would be to include other types of options (abandonment option, for example), as to study the sensitivity of NPV and ROA methods to input variables by using more sophisticated, but more complicated, methods as Monte Carlo simulation.

\section{References}

Black, F., \& Scholes, M. (1973). The pricing of options and corporate liabilities. Journal of Political Economy, 81(3), 637-654. https://doi.org/10.1086/260062

Brandão, L. E., Dyer, J., \& Hahn, W. J. (2005). Using Binomial Decision Trees to Solve Real-Option Valuation Problems. Decision Analysis Journal, 2(2), 69-88. https://doi.org/10.1287/deca.1050.0042

Brennan, M. J., \& Schwartz, E. S. (1985). Evaluating Natural resources investments. Journal of Business, 58(2), 135. https://doi.org/10.1086/296288

Capozza, D., \& Sick, G. (1994). The Risk Structure of Land Markets. Journal of Urban Economics, 35(3), 291-319. https://doi.org/10.1006/juec.1994.1018

Cortazar, G., \& E. S. Schwartz (1998). Monte Carlo Evaluation Model of an Undeveloped Oil Filed. Journal of Energy Finance and Development, 3(1), 73-84. https://doi.org/10.1016/S1085-7443(99)80069-6

Dickens, R. N., \& Lohrenz, J. (1996). Evaluating Oil and Gas Assets: Option Pricing Methods Prove No Panacea. Journal of Financial and Strategic Decision, 9(2). https://doi.org/10.1016/s1085-7443(99)80069-6

Dixit, A. K., \& Pindyck, R. S. (1995). The Options Approach to Capital Investment. Harvard Business Review, 77(3), 105-115. https://doi.org/10.1016/0024-6301(95)94305-I

Elder, J., \& Serletis, A. (2010). Oil price uncertainty. Journal of Money, Credit and Banking, 42, 1138-1159. https://doi.org/10.1111/j.1538-4616.2010.00323.x

Fan, Y., Mo, J. L., \& Zhu, L. (2013). Evaluating coal bed methane investment in china based on a real options model. Resources Policy, 38(1), 50-59. https://doi.org/10.1016/j.resourpol.2012.08.002

Fernandes, B., Cunha, J., \& Ferreira, P. (2011). The use of real options approach in energy sector investments. Renewable and Sustainable Energy Reviews, 15(9), 4491-4497. https://doi.org/10.1016/j.rser.2011.07.102

Gruy, H. J., Garb, A., \& Wood. J. W. (1982). Determining the Value of Oil and Gas in the Ground. World Oil, CXCIV, 105-108.

Haque, M., Topal, E., \& Lilford, E. (2014). A numerical study for a mining project using real options valuation under commodity price uncertainty. Resources Policy, 39(1), 115-123. https://doi.org/10.1016/j.resourpol.2013.12.004

Herder, P. M., Joode, J., Ligtvoet, A., Schenk, S., \& Taneja, P. (2010). Buying real options valuing uncertainty in infrastructure planning. Futures, 24, 1-24. https://doi.org/10.1016/j.futures.2011.06.005

Kellogg, D., \& Charnes, J. M. (2000). Real-Options Valuation for a Biotechnology Company. Financial Analysts Journal, May/June, 76-84. https://doi.org/10.2469/faj.v56.n3.2362

Lima, G., \& Suslick, S. (2006). Estimation of volatility of selected oil production projects. Journal of Petroleum science and Engineering, 129-139. https://doi.org/10.1016/j.petrol.2006.07.005

Luehrman, T. A. (1998). Investment opportunities as real options: getting started on the number. Harvard 
Business Review, 76, 51-67.

McDonald, R., \& Siegel, D. (1986). The value of waiting to invest. Quarterly Journal of Economic, 101(4), 707. https://doi.org/10.2307/1884175

Meyers, S. (1977). Determinants of Corporate Borrowing. The Journal of Financial Economics, 5(2), 147-175. https://doi.org/10.1016/0304-405x(77)90015-0

Morris, P. A., Teisberg, E. O., \& Kolbe, L. A. (1991). When choosing R\&D projects, go with long shots. Research Technology Management, Jan-Feb, 35-40. https://doi.org/10.1080/08956308.1991.11670715

Myers, S. C., \& Read, J. A. J. (2012). Real options, taxes and financial leverage. SSRN Working paper. https://doi.org/10.2139/ssrn.2072403

Paddock, J., Siegel, D., \& Smith, J. L. (1988). Option Valuation of claims on real assets: the case of offshore petroleum leases, Quarterly Journal of Economics, 103(3), 479. https://doi.org/10.2307/1885541

Pennings, E., \& Lint, O. (1997). The Option Value of Advanced R\&D. European Journal of Operational Research, 103, 83-94. https://doi.org/10.1016/s0377-2217(96)00283-4

Quigg, L. (1993). Empirical Testing of Real Option-Pricing Models. The Journal of Finance, 48(2), 621-640. https://doi.org/10.2307/2328915

Ross, S. A. (1995). Uses, Abuses, and Alternatives to the Net-Present-Value Rule. Financial management, 24(3), 96-102. https://doi.org/10.2307/3665561

Schwartz, E. S., \& Moon, M. (2000) Rational Pricing of Internet Companies. Financial Analyst Journal, 56, 62-75. https://doi.org/10.2469/faj.v56.n3.2361

Schwartz, E. S., Dixit, A. K., \& Pindyck, R. S. (1994). Investment under Uncertainty. The Journal of Finance, 49(5), 1924. https://doi.org/10.2307/2329279

Trigeorgis, L. (1990). A Real Option Application in Natural-Resource Investments. Advances in Futures and Options Research, 4, 153-156.

Trigeorgis, L., \& Manson, S. (1987). Valuing managerial flexibility. Midland Corporate Finance Journal, 5(1), $14-21$.

Zettl, M. (2002). Valuing exploration and production projects by means of option pricing theory. International Journal of Production Economics, 109-116. https://doi.org/10.1016/s0925-5273(01)00215-8

\section{Copyrights}

Copyright for this article is retained by the author(s), with first publication rights granted to the journal.

This is an open-access article distributed under the terms and conditions of the Creative Commons Attribution license (http://creativecommons.org/licenses/by/4.0/). 